\title{
Open Access Journals - A Study
}

\author{
K. Jayaprakash, A P Rekha, S Rajendiran \\ Research Scholars, (Dept. of LIS) Hindustan University, Chennai
}

\begin{abstract}
Open sources Journals plays very important role in the Libraries. "Open Access" is very essential for library and information science professionals to provide information resources to their users without any fees. Open-access journals are scholarly journals that are available online to the reader "without financial, legal, or technical barriers other than those inseparable from gaining access to the internet itself." Some are subsidized, and some require payment on behalf of the author. The open access journals has some advantages, the study has list of open access journals also.
\end{abstract}

Keywords: Open Access Journals, Open source Journals debate, List of Open source Journals, Pros and Cons, advantages.

\section{Introduction}

\section{Open Access Journals}

Present days, Open access plays the vital role in the libraries. In the digital environment of "Open Access" is very essential for library and information science professionals. Open-access journals are scholarly journals that are available online to the reader "without financial, legal, or technical barriers other than those inseparable from gaining access to the internet itself." ${ }_{(1)}$ Some are subsidized, and some require payment on behalf of the author. Subsidized journals are financed by an academic institution, learned society or a government information center; those requiring payment are typically financed by money made available to researchers for the purpose from a public or private funding agency, as part of a research grant. There have also been several modifications of open-access journals that have considerably different natures: hybrid open-access journals and delayed open-access journals.

Open-access journals are classified in to two methods. The first methods is called "gold road to open access". The other one called the "green road" method is self-archiving in a repository.

The publisher of an open-access journal is known as an "open-access publisher", and the process, "open-access is publishing". This paper presents a brief overview of the concept open access journal the potential pros and cons in library.

\section{Open Source Initiative (OSI)}

The Open Source Initiative (OSI) is a non-profit corporation formed to educate about open source (2).

\section{Open access journal: an Overview}

Many journals have been subsidized ever since the beginnings of scientific journals. It is common for those countries with developing higher educational and research facilities to subsidize the publication of the nation's scientific and academic researchers, and even to provide for others to publish in such journals, to build up the prestige of these journals and their visibility. Such subsidies have sometimes been partial, to reduce the subscription price, or total, for those readers in the respective countries, but are now often universal.

The first digital-only, free journals also called open access journal were published on the Internet in the late 1980. Among them was Bryn Mawr Classical Review, Postmodern Culture, Psycoloquy, and The PublicAccess Computer Systems Review

In 1998, one of the first open-access journals in medicine, the Journal of Medical Internet Research (JMIR) ${ }^{[13]}$ was created, publishing its first issue in 1999. One of the very first online journals, Geo Logic, Terra Nova, was published by Paul Browning and started in 1989.

\section{Kinds of open-access journals}

- Journals entirely open access

- Journals with research articles open access (hybrid open-access journals)

- Journals with some research articles open access (hybrid open-access journals)

- Journals with some articles open access and the other delayed access

- Journals with delayed open access (delayed open-access journals)

- Journals permitting self-archiving of articles 


\section{Financing open-access journals}

Open-access journals divide into those that charge publication fees and those that do not.

\section{Fee-based open-access journals}

Fee-based open-access journals require payment on behalf of the author. The money might come from the author but more often comes from the author's research grant or employer. In cases of economic hardship, many journals will waive all or part of the fee.

\section{No-fee open-access journals}

No-fee open-access journals use a variety of business models. As summarized by Peter Suber: ${ }^{[3]}$ "Some no-fee OA journals have direct or indirect subsidies from institutions like universities, laboratories, research centers, libraries, hospitals, museums, learned societies, foundations, or government agencies.

Reactions of existing publishers to open-access journal publishing have ranged from moving with enthusiasm to a new open-access business model, to experiments with providing as much free or open access as possible, to active lobbying against open-access proposals. ${ }^{[4]}$ There are many new publishers starting up as open-access publishers, with the Public Library of Science being the best-known example.

\section{For}

Advocates believe the primary advantage of open access is that the content is available to users everywhere regardless of affiliation with a subscribing library. This is intended to benefit:

- Authors: of such articles, who will see their papers more read, more cited, and better integrated into the structure of science ${ }^{[5]}$

- Academic readers: in general at institutions that cannot afford the journal, or where the journal is out of scope

- Researchers: at smaller institutions, where their library cannot afford the journal

- Readers: in general, who may be interested in the subject matter

- The general public: who will have the opportunity to see what scientific research is about

- Taxpayers: who will see the results of the research they pay for

- Patients: and those caring for them, who will be able to keep abreast of medical research

\section{Against}

There are a number of objections ${ }_{(7)}$ :

- Open access is unnecessary

- Open access is too impractical to implement

- Many fields of research have few or no good open-access journals

- The author-pays model obstructs free and open exchange of scientific results

Opponents of the open-access model assert that the pay-for-access model is necessary to ensure that the publisher is adequately compensated for their work. Scholarly journal publishers that support pay-for-access claim that the "gatekeeper" role they play, maintaining a scholarly reputation, arranging for peer review, and editing and indexing articles, require economic resources that are not supplied under an open-access model. Opponents claim that open access is not necessary to ensure fair access to developing nations; differential pricing, or financial aid from developed countries or institutions can make access to proprietary journals affordable. $^{[9]}$

\section{Pros and cons of variants}

The primary advantage of open-access journals is that the entire content is available to users everywhere regardless of affiliation with a subscribing library. In contrast, with self-archiving, only some of the journal articles are available, and it is not possible for the reader to know which they might be.

The main motivation for most authors to publish in an open-access journal is increased visibility and ultimately a citation advantage. Research citations of articles in a hybrid open-access journal have shown that open-access articles are cited more frequently or earlier than non-open-access articles. ${ }^{[10]}$

In the case of fee-based open-access journals, authors either need to have a sponsor (such as a funder or employer) to pay on their behalf, or personally pay the publication fee.

\section{Current problems and projects}

\section{Identifying open-access journals and the articles in them}

There are several major directories of open-access journals, most notably: Directory of Open Access Journals (DOAJ) and Open J-Gate.

Each has its own special standards for what journals are included. 


\title{
Major projects to provide open-access journals
}

Pioneers in open-access publishing in the biomedical domain were journals like the BMJ, Journal of Medical Internet Research, and Medscape, who were created or made their content freely accessible in the late 90s. ${ }^{[11]}$ Bio Med Central, a for-profit publisher with now dozens of open-access journals, published its first article in the year 2000. ${ }^{[12]}$ The Public Library of Science launched its first open-access journal, PLoS Biology in 2003, PLoS Medicine in 2004, and PLoS ONE in 2006. ${ }^{[12]}$

\author{
Journals Categories \\ - Medical Sciences \\ - Social Sciences \\ - Biological Sciences \\ - Agricultural Sciences \\ - Physical Sciences \\ - Engineering \\ - Arts and Education \\ - Legal Studies \\ - Other Journals
}

\author{
Medical Sciences \\ International Journal of Medicine and Medical Sciences \\ Social Sciences \\ Journal of Geography and Regional Planning \\ Biological Sciences \\ Journal of Cell and Animal Biology \\ Agricultural Sciences \\ Journal of Plant Breeding and Crop Science \\ African Journal of Agricultural Research \\ Physical Sciences \\ African Journal of Pure and Applied Chemistry \\ Engineering \\ Journal of Engineering and Technology Research
}

\section{Conclusion:}

Using open source journals are very much needed by the all kind users from students, Research scholar, Library professionals and other academicians. Present days it plays crucial role in the libraries to satisfy the users demand in all field of knowledge. When it comes to the advantages and disadvantages of open source journals, there are some definite pros and cons to consider. The main motivation for most authors to publish in an open-access journal is increased visibility and ultimately a citation advantage. A research citation of articles in a hybrid open-access journal has shown that open-access articles are cited more frequently or earlier than non-open-access articles. ${ }^{[10]}$ In the case of fee-based open-access journals, authors either need to have a sponsor (such as a funder or employer) to pay on their behalf, or personally pay the publication fee. Open-access journals are scholarly journals that are available online to the reader "without financial, legal, or technical barriers other than those inseparable from gaining access to the internet itself."

[1] Open Access Overview

[2] Budapest Open Access Initiative

[3] Suber, Peter (November 2, 2006). "No-fee open-access journals". SPARC Open Access Newsletter.

[4] Partnership for Research Integrity in Science and Medicine (article on Sourcewatch about an anti-open-access lobbying organization)

[5] Antelman, K. (2004). "Do open-access articles have a greater research impact?". College \& Research Libraries News 65 (5): $372-$ 382 .

[6] Vogel, G. Quandary: Scientists Prefer Reading Over Publishing 'Open Access' Papers. Science Online January $14,2011$.

[7] Raghavendra Gadagkar, Open-access more harm than good in developing world, Nature 453 (2008) 450. doi:10.1038/453450c

[8] DCL news editorial, Scientific literature: Who should pay - author or subscriber?

[9] [1] PRISM

[10] Citation Advantage of Open Access Articles

[11] The Open Access Advantage, Journal of Medical Internet Research

[12] $\mathbf{a}$ b Timeline

[13] JMIR 